\title{
Virulence, Cytotoxic and Inflammatory Activities of Vibrio Anguillarum and Aeromonas Salmonicida Isolated from Cultivated Salmonid Fish in Sweden
}

\author{
By Karel Krovacek, Ahmed Faris, Laila Eriksson, Eva Jansson, Olle Ljungberg \\ and Ingmar Månsson
}

\begin{abstract}
Krovacek, K., A. Faris, L. Eriksson, E. Jansson, O. Ljungberg and I. Månsson: Virulence, cytotoxic and inflammatory activities of Vibrio anguillarum and Aeromas salmonicida isolated from cultivated salmonid fish in Sweden. Acta vet. scand. 1987, 28, 47-54. - Extracellular products in culture filtrates of Aeromonas salmonicida subsp. achromogenes and Vibrio anguillarum isolated from infected fish have been shown to possess skin inflammatory factor. The extracellular products from Vibrio anguillarum were cytotoxic in $\mathrm{HeLa}$ and $\mathrm{CHO}$ cells. In addition to the skin lesions, the culture filtrates of $\mathrm{V}$. anguillarum caused necrotic reaction on the rabbit skin. Five of 6 strains of $\mathrm{V}$. anguillarum were lethal to mice after intraperitoneal administration of $3 \times 10^{7}$ CFU. Only 1 strain of 5 A. salmonicida subsp. achromogenes produced extracellular products which elicited cytotoxic effects in the $\mathrm{CHO}$ cells. None of the A. salmonicida subsp. achromogenes strains were lethal to mice. The cytotoxins were inactivated when heated at $65^{\circ} \mathrm{C}$ for $30 \mathrm{~min}$. The results indicate that the thermolabile exotoxins are non-enterotoxic since they failed to stimulate fluid accumulation in the rabbit ileal loop and did not cause elongation of the $\mathrm{CHO}$ cells. The rounding off of $\mathrm{CHO}$ cells, as well as of HeLa cells indicate that the exotoxins may play an important role in fish diseases.
\end{abstract}

Aeromonas salmonicida; Vibrio anguillarum; bacterial toxins; fish diseases; virulence factors.

\section{Introduction}

In a recent review by Austin \& Allen-Austin (1985), bacterial pathogens of fish, belonging to 25 genera, have been described as being associated with disease of fresh water as well as marine fish. The authors point out that fish diseases due to bacterial infections are major problems in aquaculture. There is therefore, a need for basic water hygiene, which when neglected may lead to the start of a disease cycle (McCarthy 1977). Research on fish diseases has so far been main- ly orientated towards pathology of the diseases, vaccination and profylactic treatment (Austin \& Allen-Austin 1985).

Infections by Aeromonas and Vibrio spp. are known to result to furunculosis and vibriosis (Austin \& Allen-Austin 1985). Both species produce a range of extracellular products (ECP) such as haemolysins, enterotoxins, proteases and endotoxins. (Bernheimer et al. 1974, Sanyal et al. 1975, Donta et al. 1978, Eurell et al. 1978, Huizinga et al. 1979, Jiwa 1983). Experimentally, it was de- 
monstrated that the ECP from some of Aeromonas and Vibrio organisms are lethal to salmoid fish (Cipriano et al. 1981, Ellis et al. 1981, Shieh et al. 1981). Thus the aim of this investigation was to biologically characterize the virulent properties of Vibrio anguillarum and Aeromonas salmonicida subsp. achromogenes and to study their extracellular products with special reference to toxin production.

\section{Materials and methods}

\section{Strains}

The clinical history of 6 strains of Vibrio anguillarum and 5 strains of Aeromonas salmonicida subsp. achromogenes, isolated from rainbow trout, grayling, sea trout and char is summarized in Table 1. All strains were isolated from fish with clinical symptoms in fish farms with disease outbreaks.

Main source of isolation was the kidney; but strain B 98 (A. salmonicida subsp. achromogenes) was isolated from grayling skin sore. Pathological changes of the diseased fish ranged from muscular and fin bleeding to skin sore, and sloughing off of scales. In general, the fish (Table 1) underwent tissue damage of one form or another, apart from 1 sea and 1 rainbow trouts which lacked post mortem findings of interests.

\section{Growth condition}

Strains were streaked onto blood (5\% horse blood) agar with $2 \% \mathrm{NaCl}$ and incubated 48 $\mathrm{h}$ at $20^{\circ} \mathrm{C}$. Thereafter the bacteria were harvested and inoculated into $50 \mathrm{ml}$ Trypticase yeast broth in shaker flasks for $48 \mathrm{~h}$ at $20^{\circ} \mathrm{C}$. The cultures were centrifuged at $16.000 \mathrm{xg}$ at $4^{\circ} \mathrm{C}$ for $30 \mathrm{~min}$ and the supernatants were then millipore filtered (Millipore filter 0.22 $\mu \mathrm{m})$. Sterile cell-free culture filtrates were then immediately tested for cytotoxic and hemolytic activities or aliquoted and frozen at $-20^{\circ} \mathrm{C}$ for later studies in the rabbit skin test and the rabbit ileal loop test.

\section{Assay of haemolytic activity}

Haemolytic activity was detected by washed $1 \%$ sheep erythrocyte suspension in phosphate buffered saline (PBS) (pH 7.0). $100 \mu \mathrm{l}$ culture filtrates were 2 -fold diluted with PBS in microtitre plates with U-shaped wells. Sheep erythrocytes $(100 \mu \mathrm{l})$ were added into each microtitre well. The plate was incubated for $1 \mathrm{~h}$ at $37^{\circ} \mathrm{C}$ and afterwards for $24 \mathrm{~h}$ at $4^{\circ} \mathrm{C}$. The haemolysin activity-titer was measured visually.

Assay of cytotoxic activity

Aeromonas and Vibrio isolates were examined for their ability to produce cytotoxin with activity to Chinese hamster ovary cells $(\mathrm{CHO})$ and $\mathrm{HeLa}$ cells. Cells $\left(2 \times 10^{6}\right.$ cells $/ \mathrm{ml}$ ) were seeded in each well of a 96-well microtiter plate containing $200 \mu \mathrm{l}$ of Hams-F12 medium supplemented with $10 \%$ foetal calf serum, 1\% L-glutamine (200 $\mathrm{mM})$, penicillin-G (100 units $/ \mathrm{ml})$ and streptomycin $(100 \mu \mathrm{l} / \mathrm{ml})$. The plates were incubated at $37^{\circ} \mathrm{C}$ for $2-3$ days for formation of monolayers in a humidified atmosphere of $95 \%$ air and $5 \% \mathrm{CO}_{2}$. Fifty microliters (50 $\mu \mathrm{l})$ of two-fold diluted culture filtrates were added into each well of monolayer containing fresh complete Hams-F12 medium. After $18 \mathrm{~h}$ of incubation as above, the cells were microscopically examined for any form of destruction or morphological alterations (Janda et al. 1985).

\section{Rabbit skin assay}

$48 \mathrm{~h}$ culture filtrates were tested in the rabbit skin test in 2 to $2.5 \mathrm{~kg}$ New Zealand white rabbits. Evans blue $(5 \% \mathrm{w} / \mathrm{v})$ was injected intravenously $18 \mathrm{~h}$ after $0.1 \mathrm{ml}$ intradermal injection of test samples and the test was read $1 \mathrm{~h}$ later (Sandefur \& Peterson 1976). 
Karel Krovacek, Ahmed Faris, Laila Eriksson, Eva Jansson, Olle Ljungberg and Ingmar Mänsson: Virulence, Cytotoxic and Inflammatory Activities of Vibrio Anguillarum and Aeromonas Salmonicida Isolated from Cultivated Salmonid Fish in Sweden.

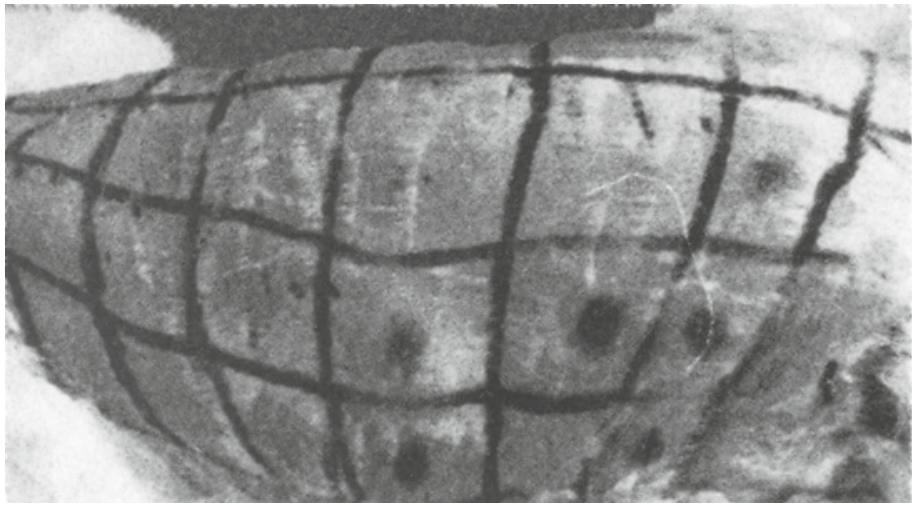

Figure 1. Rabbit skin showing induration and necrosis caused by Vibrio anguillarum culture filtrate.

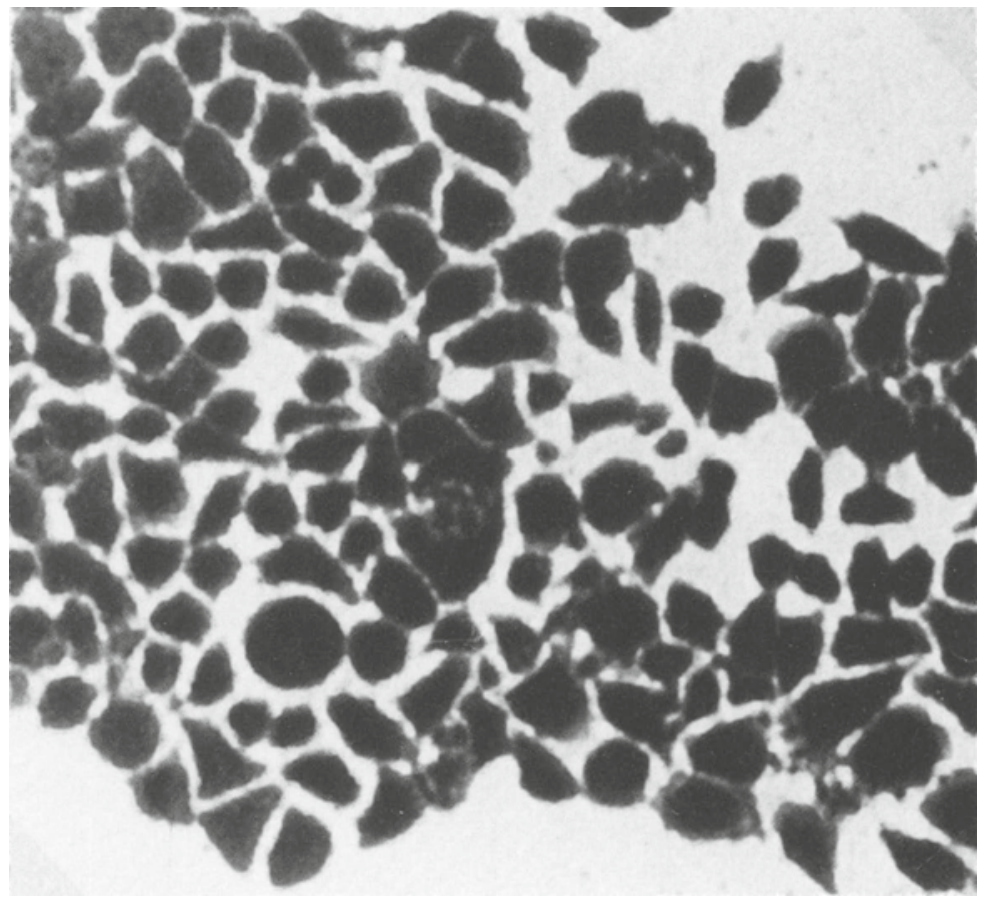

Figure 2. Untreated normal Chinese hamster ovary cells. 


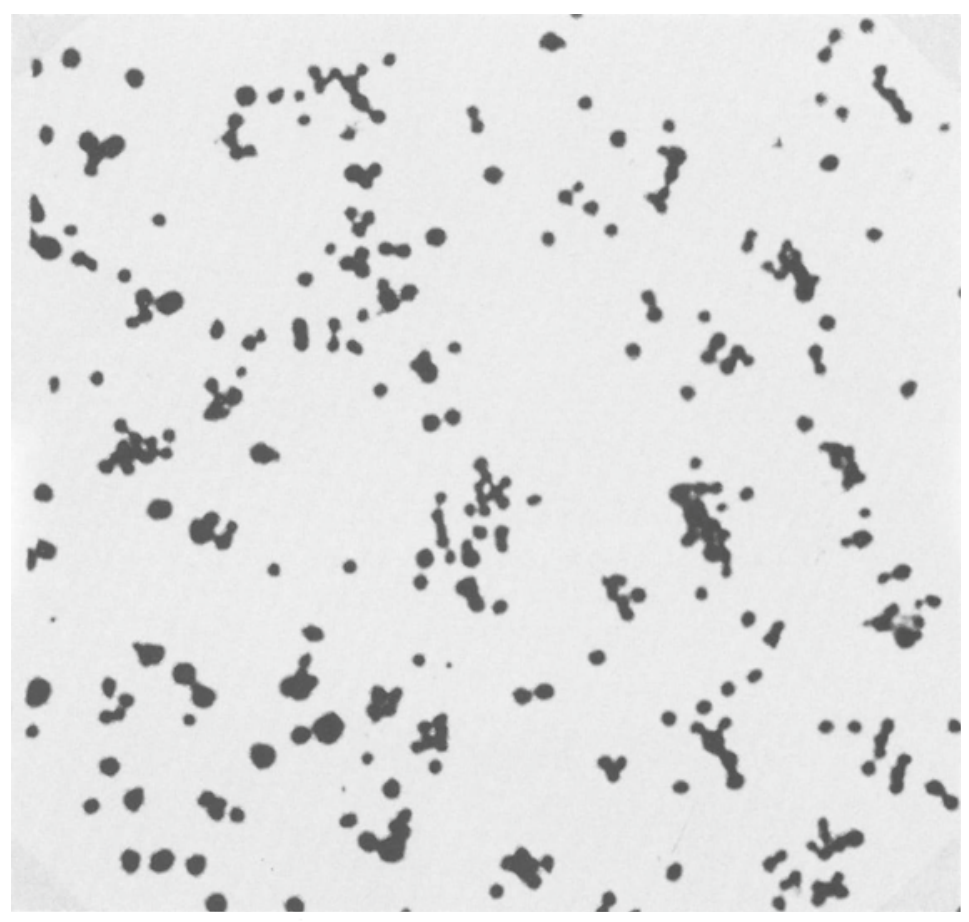

Figure 3. Cytotoxic effect in Chinesé hamster ovary cells caused by culture filtrate of Vibrio anguillarum.

Figure 4.Effect in HeLa cells $24 \mathrm{~h}$ after exposure to Vibrio anguillarum culture filtrate.

(A) untreated normal HeLa cells, (B) rounding effect and loss of adherence, (C) destruction of monolayer, (D) lysis and death of cells. 

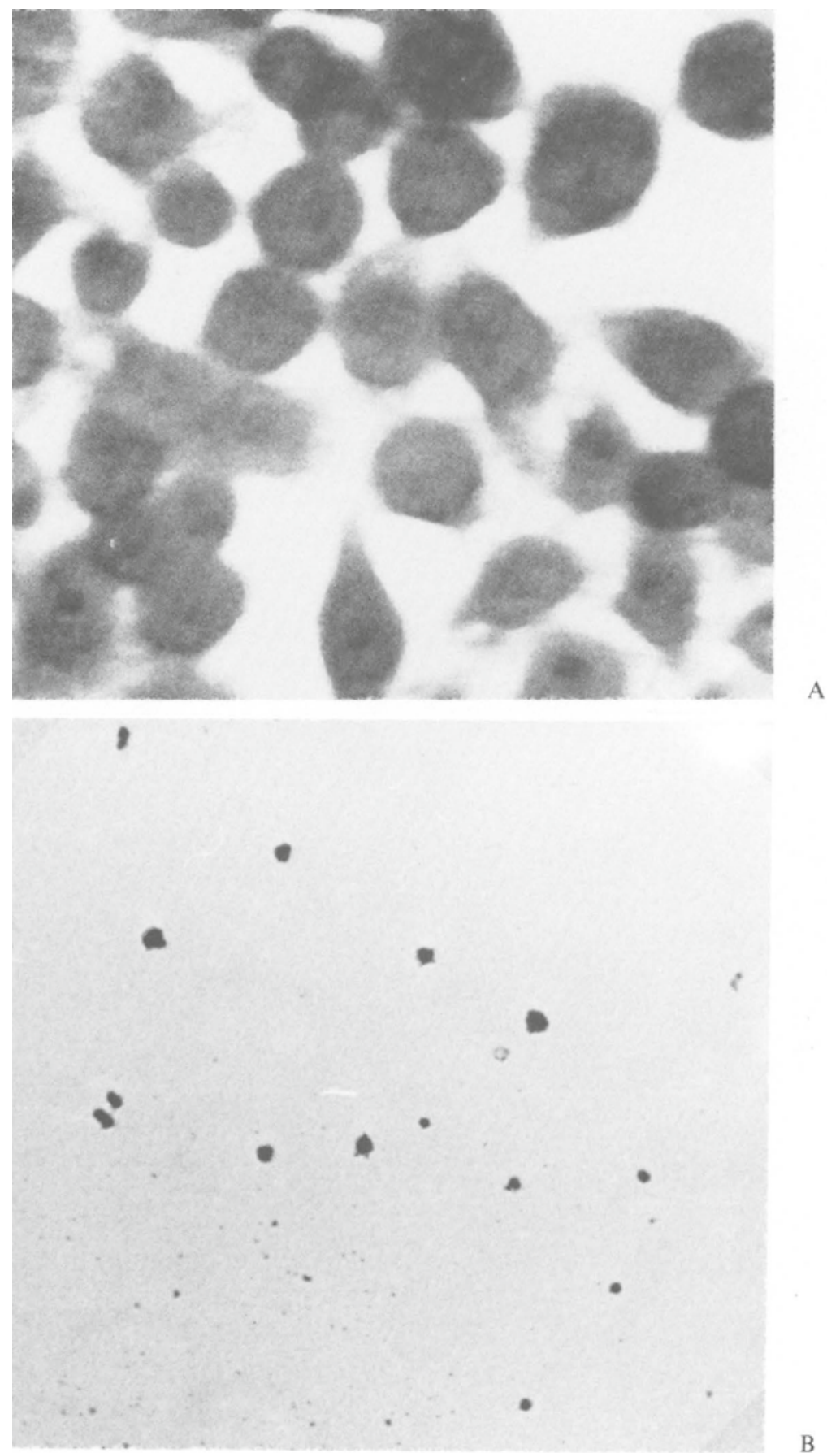


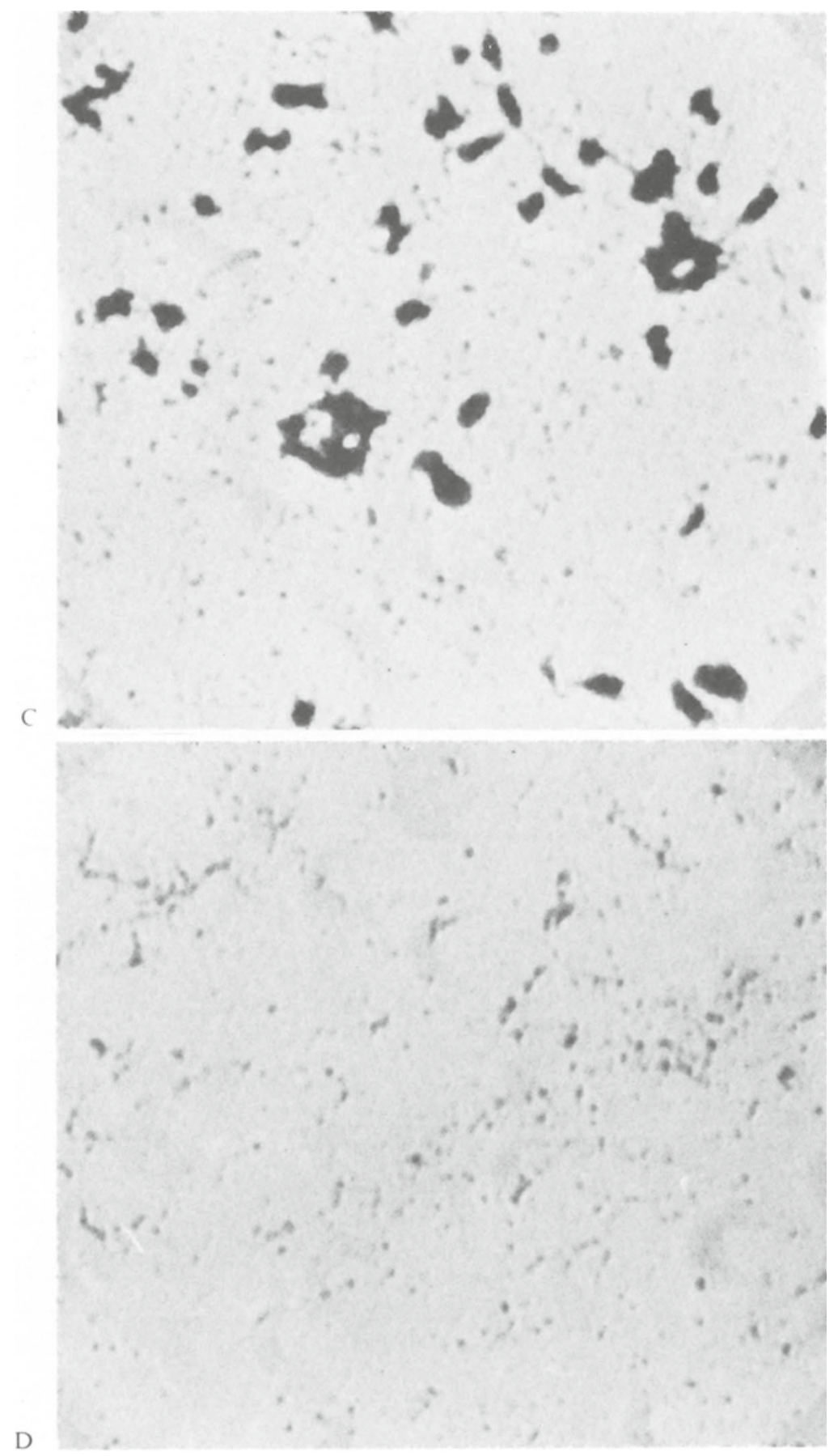


Table 1. Clinical history of fish from which Vibrio anguillarum and Aeromonas salmonicida subsp. achromogenes were isolated.

\begin{tabular}{|c|c|c|c|c|c|}
\hline Strain no. & $\begin{array}{c}\text { Species and } \\
\text { type }\end{array}$ & Host & $\begin{array}{l}\text { Bacteria isolated } \\
\text { from }\end{array}$ & $\begin{array}{c}\text { Date for } \\
\text { primary isolation }\end{array}$ & Gross pathology \\
\hline В 2158 & Va 1 & Rainbow trout & Kidney & 840923 & Not investigated \\
\hline B 2362 & Va 1 & Rainbow trout & Kidney & 841012 & Muscular bleeding \\
\hline В 1924 & Va 1 & Rainbow trout & Kidney & 850709 & $\begin{array}{l}\text { Muscular bleeding, } \\
\text { skin lesion }\end{array}$ \\
\hline В 2294 & Va 1 & Rainbow trout & Kidney & 850806 & Skin lesion \\
\hline В 2299 & Va 1 & Rainbow trout & Kidney & 850806 & Muscular bleeding \\
\hline B 2362 & Va 2 & Rainbow trout & Kidney & 841012 & Muscular bleeding \\
\hline В 98 & ASA & Grayling & Skin lesion & 850114 & $\begin{array}{l}\text { Sloughing off of } \\
\text { scales, skin lesion }\end{array}$ \\
\hline В 1675 & ASA & Sea trout & Kidney & 850607 & $\begin{array}{l}\text { Bleeding at the fin } \\
\text { basal region }\end{array}$ \\
\hline B 1957 & ASA & Sea trout & Kidney & 850710 & Pectoral fin damaged, \\
\hline В 2296 & ASA & Char & Kidney & 850806 & $\begin{array}{l}\text { Bleeding at the basal } \\
\text { region of pectoral } \\
\text { fin skin lesion }\end{array}$ \\
\hline В 2502 & ASA & Sea trout & Kidney & 850823 & Negative \\
\hline
\end{tabular}

Va 1: Vibrio anguillarum, serotype 1.

Va 2: Vibrio anguillarum, serotype 2.

ASA: Aeromonas salmonicida subsp. achromogenes.

Rabbit ileal loop test

$1 \mathrm{ml} 48 \mathrm{~h}$ culture filtrates were tested in rabbit ileal loop test. Intestinal fluid accumulation were measured after $18 \mathrm{~h}$ for detection of enterotoxin effects (Sanyal et al. 1975).

\section{Mouse lethality test}

The strains were incubated on horse blood agar for $48 \mathrm{~h}$ at $20^{\circ} \mathrm{C}$. The cultures were suspended in physiological saline, pelleted and washed in saline prior to photometric standardization of the suspension to $3 \times 10^{8}$ $\mathrm{CFU} / \mathrm{ml}\left(\mathrm{OD} 0.4\right.$ at $\mathrm{A}_{430 \mathrm{~mm}}^{10 \mathrm{~mm}}$ ). For each strain 5 albino mice weighing 20-25 g each were injected intraperitoneally with $200 \mu \mathrm{l}$ of the bacterial inoculum $\left(6 \times 10^{7} \mathrm{CFU}\right)$. The mice were observed daily for 1 week for determination of the pathogenicity of the strains (Janda et al. 1985).

\section{Results}

\section{Cultural conditions on agar}

Cultures on $5 \%$ horse blood agar with and without $2 \% \mathrm{NaCl}$ at $20^{\circ} \mathrm{C}$ showed that Vibrio strains grew as medium size colonies as compared to the small Aeromonas colonies, after 16-24 h. Colonies of Aeromonas salmonicida subsp. achromogenes on blood agar, in contrast to those of Vibrio, were compact and on harvest, they dislocated from the agar surface as separate entities.

\section{Biochemical tests}

Biochemical profiles of and differences between Vibrio and Aeromonas strains showed that Vibrios fermented maltose, were indole, arginine, Voges-Proskauer and citrate positive. They produced amylase (starch hydrolysis positive). The Aeromonas strains were 
Table 2. Biochemical and other characteristics of Vibrio anguillarum and Aeromonas salmonicida subsp. achromogenes isolated from different fish.

\begin{tabular}{|c|c|c|c|c|c|c|c|c|c|c|c|}
\hline \multirow[b]{2}{*}{$\begin{array}{l}\text { Biochemical } \\
\text { tests }\end{array}$} & \multicolumn{6}{|c|}{ Vibrio anguillarum } & \multicolumn{5}{|c|}{ A. salmonicida subsp. achromogenes } \\
\hline & B 2158 & $\begin{array}{l}\text { B } 2362 \\
\text { (Va 2) }\end{array}$ & $\begin{array}{l}\text { B2362 } \\
\text { (Va 1) }\end{array}$ & B 1924 & В 2294 & B 2299 & В 98 & B 1675 & В 2296 & B 2502 & B 1957 \\
\hline Va 1 typing antisera & + & - & + & + & + & + & NT & NT & NT & NT & NT \\
\hline Va 2 typing antisera & - & + & - & - & - & - & & & & & \\
\hline Ramnose & - & - & - & - & - & - & - & - & - & - & - \\
\hline Glucose & a & a & a & $\mathrm{a}$ & a & a & a & a & a & a & $\mathrm{a}$ \\
\hline Lactose & - & - & - & - & - & - & - & - & - & - & - \\
\hline Maltose & a & a & a & a & a & a & $(-)$ & - & - & - & - \\
\hline Saccharose & a & a & a & a & a & a & $\mathrm{a}$ & a & a & a & $\mathrm{a}$ \\
\hline Indole & + & + & + & + & + & + & - & - & - & - & - \\
\hline OF & $+/+$ & $+/+$ & $+/+$ & $+/+$ & $+/+$ & $+/+$ & $+/+$ & $+/+$ & $+/+$ & $+/+$ & $+/+$ \\
\hline Motility & + & + & + & + & + & + & - & - & - & - & - \\
\hline $15^{\circ} \mathrm{C}$ & + & + & + & + & + & + & + & + & + & + & + \\
\hline $24^{\circ} \mathrm{C}$ growth & + & + & + & + & + & + & + & + & + & + & + \\
\hline $37^{\circ} \mathrm{C} J$ at & - & $(+)$ & - & - & - & - & - & - & - & - & - \\
\hline Arginine & + & + & + & + & + & + & - & + & - & - & - \\
\hline Ornithine & - & - & - & - & - & - & - & - & - & - & - \\
\hline Lysine & - & - & - & - & - & - & - & - & - & - & - \\
\hline MR & - & - & - & - & - & - & + & - & + & - & + \\
\hline VP & + & - & + & + & + & + & - & - & - & - & - \\
\hline Gelatine & + & + & + & + & + & + & + & + & + & + & + \\
\hline Aesculin & - & - & - & - & - & - & - & - & - & - & - \\
\hline Starch & + & + & + & + & + & + & - & $(-)$ & - & - & - \\
\hline $\begin{array}{l}\text { Vibriostat } 0129 \\
\quad 150 \mu \mathrm{g}, 10 \mu \mathrm{g}\end{array}$ & $H$ & H & + & + & $H$ & + & NT & NT & NT & NT & NT \\
\hline
\end{tabular}

a $=$ acid production.

$\mathrm{NT}=$ not tested.

negative on these tests, and were non-motile. Two Aeromonas strains were negative on the MR test, and only 1 strain (B 1675) was arginine dihydrolase positive. However, $\mathrm{Vi}$ brio anguillarum, strain B 2362 (serotype 2), differed from the other Vibrios by its negative VP reaction (Table 2 ).

\section{Skin test}

Intradermal inoculation of $20^{\circ} \mathrm{C}$-grown culture filtrates of Vibrio and Aeromonas strains (Table 1), in the rabbit skin test gave induration of the skin in the average size of $14 \mathrm{~mm}$ (Table 3). Culture filtrates heated at $65^{\circ} \mathrm{C}$ for $30 \mathrm{~min}$ were inactivated. As can be seen in Table 3, the induration factor was best produced extracellularly into the medium at $20^{\circ} \mathrm{C}$. Bacterial sonicates did not give any form of skin reaction. The culture filtrates on rabbit skin were also found to give necrotic reactions which were eliminated by heating the samples at $65^{\circ} \mathrm{C}$ for 30 min (Table 3). Necrosis was not associated with haemolysin production, since all the 
Table 3. Effect of growth temperature on induration activity of culture filtrate from Aeromonas salmonicida subsp. achromogenes and Vibrio anguillarum in rabbit skin test.

\begin{tabular}{lccccccc}
\hline & & \multicolumn{3}{c}{$20^{\circ} \mathrm{C}$} & & \multicolumn{2}{c}{$30^{\circ} \mathrm{C}$} \\
\cline { 5 - 6 } \cline { 7 - 8 } Strain & $4^{*} \mathrm{C}$ & $1^{\circ} \mathrm{C}$ & $\begin{array}{c}\text { induration } \\
(\mathrm{mm})\end{array}$ & necrosis & & $\begin{array}{c}\text { induration } \\
(\mathrm{mm})\end{array}$ & necrosis \\
\hline B 98 ASA & $\mathrm{ND}^{\mathrm{a}}$ & 0 & 16 & - & & 0 & - \\
B 1675 ASA & ND & 0 & 16 & - & & 0 & - \\
B 2296 ASA & ND & 0 & 9 & - & & 8 & - \\
B 1957 ASA & ND & 0 & 8 & - & & 0 & - \\
B 2502 ASA & ND & 0 & 8 & - & & 0 & - \\
B 2158 Va 1 & 0 & 0 & 24 & + & & 0 & - \\
B 2362 Va 1 & 0 & 0 & 25 & + & & 0 & - \\
B 2362 Va 2 & 0 & 0 & 23 & + & & 0 & - \\
B 2294 Va 1 & 0 & 0 & 23 & + & & 0 & - \\
B 2299 Va 1 & 0 & 0 & 24 & + & & 0 & - \\
B 1924 Va 1 & 0 & 0 & 24 & + & & 15 & + \\
\hline
\end{tabular}

${ }^{a}$ not done.

strains, with the exception of strain B 2362, were non-haemolytic. Strain B 2362 (serotype 2) was haemolytic at the 1:2 dilution (Table 4), and haemolytic on horse agar plates.
Cytotoxic and mouse lethality properties None of the strains listed in Table 1 were enterotoxin positive in the rabbit ileal loop test. However, when Chinese hamster ovary $(\mathrm{CHO})$ cells were used, for detection of ex-

Table 4. Haemolytic, cytotoxic and mouse lethality properties of Aeromonas salmonicida subsp. achromogenes and Vibrio anguillarum.

\begin{tabular}{|c|c|c|c|c|}
\hline \multirow[t]{2}{*}{ Strain } & \multirow[t]{2}{*}{ Haemolytic activity ${ }^{a}$} & \multicolumn{2}{|c|}{ Cytotoxin $^{\mathrm{b}}$} & \multirow[t]{2}{*}{ Mouse lethality } \\
\hline & & $\mathrm{CHO}$ & HeLa & \\
\hline B 98 ASA & - & - & - & $0 / 5$ \\
\hline B 1676 ASA & - & + & - & $0 / 5$ \\
\hline B 2296 ASA & - & - & - & $0 / 5$ \\
\hline B 1957 ASA & - & - & - & $0 / 5$ \\
\hline B 2502 ASA & - & - & - & $0 / 5$ \\
\hline B $2158 \mathrm{Va} 1$ & - & + & + & $2 / 5$ \\
\hline B 2362 Va 1 & - & + & + & $0 / 5$ \\
\hline B 2362 Va 2 & $t^{c}$ & + & + & $5 / 5$ \\
\hline B 2294 Va 1 & - & + & + & $5 / 5$ \\
\hline B 2299 Va 1 & - & + & + & $5 / 5$ \\
\hline B 1924 Va 1 & - & + & + & $3 / 5$ \\
\hline
\end{tabular}

\footnotetext{
a against sheep erythrocytes.

b against Chinese hamster ovary (CHO) cells and HeLa cells.

${ }^{c}$ haemolysin positive at the 1:2 dilution.
} 
tra-cellular toxic products in the cell-free filtrates, morphological changes were demonstrated by all the Vibrio strains and 1 Aeromonas strain B 1675 ASA (Table 4). The other Aeromonas strains were negative. All toxic properties of the Vibrio and 1 Aeromonas cell-free filtrates were inactivated at $65^{\circ} \mathrm{C}$ for $30 \mathrm{~min}$. The unheated filtrates caused rounding off (Fig. 3) of the $\mathrm{CHO}$ cells, a phenomenon comparatively different from the typical $\mathrm{CHO}$ elongation caused by E. coli LT enterotoxin. None of the cytotoxins from the individual strains under these experimental conditions were cytoinvasive to the $\mathrm{CHO}$ cells. When HeLa cells were used, they underwent shrinkage, loss of adherence to the plastic surface of tissue culture plates and cell death.

\section{Mouse lethality test}

Mouse lethality tests for virulence of the individual strains suggested that intraperitoneal inoculation of $6 \times 10^{7}$ bacteria harvested from blood agar cultures of Vibrio anguillarum was effective in determining the virulence status of the Vibrio strains. As can be seen in Table 4 mice infected by B 2362 Va2, B $2294 \mathrm{Va} 1$, and B $2299 \mathrm{Val}$ followed by B $1924 \mathrm{Val}$ and B $2158 \mathrm{Val}$ died in great numbers. Although strain B $2362 \mathrm{Val}$ was cytotoxic in the $\mathrm{CHO}$ and HeLa cell tissue culture test systems, none of the mice infected by this strain died during the experimental period (Table 4). Mice infected by Aeromonas salmonicida subsp. achromogenes survived during the experiment.

\section{Discussion}

Our studies show that HeLa and $\mathrm{CHO}$ cells detect measureable amounts of cytotoxic acticity in culture filtrates of Aeromonas salmonicida subsp. achromogenes and Vibrio anguillarum. As indicated in Fig. 4a-d HeLa cell line is most sensitive for detection of the cytotoxin(s). Such products, from V. anguillarum cause detachment, lysis, and destruction of HeLa cells from the tissue culture plates. Damage of HeLa cells by V. anguillarum extracellular products corresponds to the necrotic activity observed on the rabbit skin.

Using CHO cells, it was possible to show differences between the morphological change caused by E.coli enterotoxins, and the extracellular products from the fish pathogens herein investigated. E. coli and V. cholerae enterotoxins cause elongation of $\mathrm{CHO}$ cells (Guerrant et al. 1974) whereas the susceptibility of $\mathrm{CHO}$ cells to the culture filtrates of the strains is expressed as rounding off of such cells (Table 4). In addition it is known as well that E. coli heat-labile enterotoxins have no effect on HeLa cells (Janda et al. 1983). These observations and the negative rabbit ileal loop test, thus confirm the non-enterotoxigenicity of $\mathrm{V}$. anguillarum and A. salmonicida subsp. achromogenes fish pathogens listed in Table 1.

On the basis of the findings shown in Fig. 1, the skin test may be used as one of the biological indicators of virulence of the investigated strains or other fish pathogens. However, infection studies in fish will be relevant to perform in future to testify the relevance of these tests in a fish model. Still the skin reactions in Table 3 resemble the fish skin lesions from which the organism were isolated (Table 1). Other investigators have used the rabbit skin test to detect tissue-damaging heat-labile enterotoxin from A. hydrophila (Dubey \& Sanyal 1978). Similar skin damage has been observed in fish after spontaneous infection with A. hydrophila (Huizinga et al. 1979). These authors reported small surface lesions, sloughing of scales, local haemorrhage and septicaemia. In this connection it seems that the findings herein reported, on the extracellular products of 
Vibrio anguillarum and Aeromonas salmonicida subsp. achromogenes are interesting and further characterization is necessary since reports by Sakai (1977) and Hsu et al. (1981) showed that extracellular protease produced by A. salmonicida and A. hydrophila are responsible for their virulence. We still do not now to what extent the rabbit skin reactions described here are due to proteolytic products. Furthermore, the negative mouse lethality test should not be negatively interpreted as the strains may still be virulent to fish. We would like to emphasize as well that the high virulence of V. anguillarum and the avirulent properties of A. salmonicida subsp. achromogenes in the mouse lethality test is correlated to the products produced by these organisms. It was further found that the main differences between V. anguillarum and A. salmonicida subsp. achromogenes in their biochemical profiles were mainly on fermentation of maltose, indole reaction and production of arginine dihydrolase. V. anguillarum were positive in these tests. We found no link between the biochemical profiles, and the organisms' cytotoxicity.

\section{Acknowledgements}

We wish to express our sincere gratitude to Birgitta Evemar and Rakel Axelsson for the preparation of the manuscript.

\section{References}

Austin B, Allen-Austin D: A review. Bacterial pathogens of fish. J. appl. Bact. 1985, 58, 483 -506 .

Bernheimer AW, Avigad LS: Partial characterization of aerolysin, lytic exotoxin from Aeromonas hydrophila. Infect. Immun. 1974, 9, 1016-1021.

Cipriano RC, Griffin BR, Lidgerding BC: Aeromonas salmonicida: Relationship between extracellular products and isolate virulence.
Canadian J. Fish. Aquatic Sciences 1981, 38, 1322-1326.

Donta ST, Hadow AD: Cytotoxic activity of Aeromonas hydrophila. Infect. Immun, 1978, 21, 989-993.

Dubey RS, Sanyal SC: Enterotoxigenicity of Aeromonas hydrophila: Skin responses and in vivo neutralization. Zbl. Bakt. Hyg., I. Abt. Orig. 1978, A242, 487-499.

Ellis AE, Hastings TS, Munro ALS: The role of Aeromonas salmonicida extracellular products in the pathology of furunculosis. J. Fish Dis. 1981, 4, 41-51.

Eurell TE, Lewis DH, Grumbles LC: Comparison of selected diagnostic tests for detection of motile Aeromonas septicaemia in fish. Amer. J. vet. Res.1978, 39, 1384-1386.

Guerrant RL, Brunton LL, Schnaitman TC, Rebhun I, Gilman AG: Cyclic adenosine monophosphate and alteration of Chinese hamster ovary cell morphology: A rapid, sensitive in vitro assay for the enterotoxins of Vibrio cholerae and Escherichia coli. Infect. Immun. 1974, 10, 320-327.

Huizinga $H W$, Esh GW, Hazen TC: Histopathology of red sore disease (Aeromonas hydrophila) in naturally and experimentally infected largemouth bass Micropterus salmoides. J. Fish Dis. 1979, 2, 263-277.

Hsu TC, Waltman WD, Shotts EB: Correlation of extracellular enzymatic activity and biochemical characteristics with regard to virulence of Aeromonas hydrophila. Develop. Biol. Stand. 1981, 49, 101-111.

Janda JM, Clark RB, Brenden $R$ : Virulence of Aeromonas species as assessed through mouse lethality studies. Curr. Micr. 1985, 12, 163-168.

Janda JM, Bottone EJ, Skinner CV, Calcaterra $D$ : Phenotypic markers associated with gastrointestinal Aeromonas hydrophila isolates from symptomatic children. J. clin. Micr. 1983, 17, 588-591.

Jiwa SFH: Enterotoxigenicity, haemagglutination and cell-surface hydrophobicity in Aeromonas hydrophila, A. sobria and A. salmonicida. Vet. Microb. 1983, 8, 17-34. 
McCarthy DH: Some ecological aspects of the bacterial fish pathogen Aeromonas salmonicida. Aqua Microb. Symposium No 6 of the Society for Applied Bacterol. 1977, 299-324.

Sakai DK: Causative factors of Aeromonas salmonicida in salmonid furunculosis: extracellular protease. Scientific reports of the Hokkaido Fish Hatchery 1977, 32, 61-89.

Sanyal SC, Singh SJ, Sen PC: Enteropathogenicity of Aeromonas hydrophila and Plesimonas shigelloides. J. med. Microb. 1975, 8, 195-199.

Sandefur PD, Peterson JW: Isolation of skin permeability factors from culture filtrates of salmonella typhimurium. Infect. Immun. 1976, 14, 671-679.

Shieh HS: Lethality of Aeromonas salmonicida to fish. Microb. Lett. 1981, 18, 29-32.

\section{Sammanfattning}

Virulens, cytoxisk och inflammatorisk aktivitet hos Vibrio anguillarum och Aeromonas salmonicida isolerad från odlad laxfisk $i$ Sverige.

Genom att använda olika biologiska tester kan man demonstrera hur Aeromonas salmonicida subsp. achromogenes och Vibrio anguillarum d.v.s. fiskpatogena bakterier producerar extracellulära produkter. Dessa extracellulära produkter i bakteriella kulturfiltrat är cytotoxiska för $\mathrm{HeLa}$ och $\mathrm{CHO}$ cell linjer och orsakar inflammatoriska och nekrotiska reaktioner i kanin hud. Genom upphettning av kulturfiltrat till $65^{\circ} \mathrm{C}$ under 30 min inaktiveras dessa effekter. Fem av 6 Vibrio anguillarum stammar var lethala för möss efter intraperitoneal administration av $3 \times 10^{7}$ CFU. Ingen stam av Aeromonas salmonicida subsp. achromogenes var lethal för möss.

(Received December 23, 1986).

Reprints may be requested from: Karel Krovacek, Dept. of Vet. Microbiol., Sect. of Bacteriology and Epizootiology, Swedish University of Agricultural Sciences, Biomedicum, Box 583, S-75123 Uppsala, Sweden. 